\title{
TEACHER DEVELOPMENT THROUGH REFLECTIVE PRACTICE
}

Laxman Gnawali*

Abstract

How can teachers learn to understand themselves? Who and what can help them in this process? This paper attempts to establish that reflection is a key for teachers to explore not only their selves but also that of the others. When teachers carry out systematic enquiry

into themselves, they will understand themselves, their practices and their learners. By constantly looking into their own actions and experiences, they can professionally grow in their own work places. This paper discusses the process of reflection and how it actually works for teacher professional development.
One major aim of education is to help learners to understand themselves as persons and as individuals. In other words, the education is meant to enable learners to inquire not only without but also within. This aim can be achieved only if the teacher can create a situation in which such inquiry is possible. In order to act as such a catalyst the teacher must be equipped with such skills because if the teacher is not involved in the endeavour to understand herself, can neither she do much in understanding others nor in helping others to understand themselves (Jersild, 1995, p. 13). She will continue to see the learners through her own unrecognised subjective impulses using her own personal world view. Now the questions arise: How can teachers learn to understand themselves? Who and what can help them in this process? The professional literature answers through 'reflection' (Dewey 1938, Schon 1991, Wallace 1991). Through reflection, teachers can explore their selves and that of the others. When teachers carry out systematic enquiry into themselves, they will understand themselves, their practices and their learners.

Miller (1990) says learning becomes a major process in teaching when the teacher becomes reflective, focused and conscious in teaching, when she starts inquiring to understand the processes going on around her, and when she takes herself into account as the object of inquiry (p. 45). Teachers normally work on 'autopilot' (Tripp, 1985) and become ritualised in their behaviour. The training programmes need to help teachers to develop the habits of reflection so that they take informed actions.

Every teacher has her personal theory of teaching and learning which Kelly (1955) calls personal 'constructs'. They make their own sense of, and have understandings of, people and events based on these constructs. They make decisions to act on the basis of this sense and understanding. In order for teachers to transform, they need to adapt their constructs which will help fit or map the

* School of Education, Kathmandu University 
old understanding with the new ones and to reach a common understanding together with others (Williams and Burden, 1997, p. 28). As Holly (1993) says 'adult learning is a complex transformation which can benefit from focused awareness' (p. 59). Reflection is the key to raising focused awareness and a pre-requisite for any altering of personal constructs.

Similar to Kelly's (1955) theory of altering mental constructs, Bartlett talks of behaviour modification. He says,

'modification of our behaviour ... requires deliberation and analysis of our ideas about teaching as a form of action based on our changed understandings'. (Bartlett, 1990, p. 203)

Such deliberation requires looking back on the past actions and experiences and learning from them. In order to explore whether they are teachers acting in accordance with their beliefs, whether what they think they are doing and what they are actually doing are in harmony, teachers need to follow reflective practice. Reflection which is to assess 'the origins, purposes and consequences of his or her work at all levels' (Zeichner and Liston, 1985 as cited in Bartlett, 1990, p. 202) leads teachers to explore the underlying meanings of events going around them and their own actions.

Williams and Burden see reflection as a process of bringing out one's own implicit knowledge and personal theories. They say

The task of the reflective practitioner is to make this tacit or implicit knowledge explicit by reflection on action, by constantly generating questions and checking our emerging theories with both personal past experiences and with the reflection of others (Williams \& Burden, 1997, p. 54).

Whereas Williams and Burden emphasise reflection to make underlying theories explicit, Ruddock (1984, p. 4) regards it as matter of professional responsibility.
Not to examine one's practice is irresponsible; to regard teaching as an experiment and to monitor one's performance is a responsible act.

Teacher educators need to understand that teacher preparation means developing in teachers low-inference skills such as giving instructions or asking questions as well as high inference skills such as planning and decision making (Wajnryb, 1992, p. 10, Richards and Nunan 1990, p. 4). Prabhu (1987 as quoted in Wajnryb 1992, p. 11) conceptualises this idea as 'equipping' which means providing teachers with pedagogical knowledge and skills for immediate use, and 'enabling' meaning helping teachers to develop ability to independently handle professional affairs. Training can 'equip' teachers with low inference skills but to 'enable' them with high inference skills teachers need to be involved in reflective practice.

Bartlett (1990, p. 209) presents a five step reflective cycle: mapping, informing, contesting, appraising and acting. At the mapping step, teacher observes and collects evidences about her own teaching. By using diary, journals, audio or video means, the teacher takes the first step in reflecting on and about practice. In the second step, which is informing, the teacher having mapped her images in relation to teaching, tries to look for meaning behind the maps.

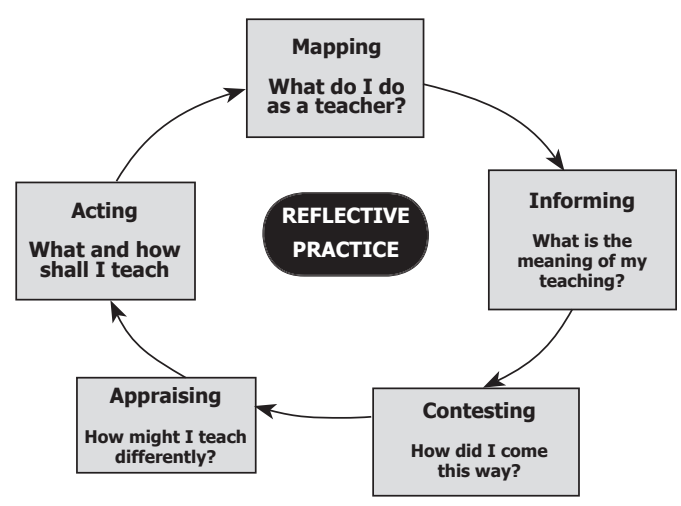

The process of reflective teaching. Adapted from Bartlett (1990, p. 209) 
This can be better done by sharing maps with colleagues. In the third step, the teacher tries to find the underlying reasons and background for the behaviour. Contesting involves looking for inconsistencies and contradictions in one's own thinking and doing. Having established the contradictions in principles and behaviour, at the appraising step the teacher goes on to find out alternative ways of her teaching which are consistent to her understanding. Then at the fifth step, which is acting, the teacher acts in the way envisioned in the appraising. If this acting does not bring about expected results, the second cycle of reflective teaching begins.

This five stage reflective cycle is a generic concept because this reflection process can be realised simply as described above or through different activities. The focus point is professionals involved in teacher development need to 'enable' teachers to undertake reflective practice as an integral part of their classroom teaching.

\section{References}

Bartlett, L. (1990). Teacher development through reflective teaching. In J. C. Richards and D. Nunan (Eds.) Second language teacher education. Cambridge: Cambridge University Press.

Dewey, J. (1938). Education and experience. New York: Collier Macmillan.
Holly, M. L. (1993). Personal and professional learning: On teaching and self-knowledge. In G. Plummer and G. Edwards (Eds.) CARN critical conversations; A triology Book 2 - Dimensions of action research: People, practice and power. Bournmouth: Hyde.

Jersild, A. (1955). When teachers face themselves. New York: Teachers College Press.

Kelly, G. (1955). The psychology of personal constructs: A theory of personality, 1. New York: Norton.

Miller, A. ((1990). Banished Knowledge: Facing Childhood Injuries. New York: Doubleday.

Richards, J. C. and D. Nunan (1990). Issues and Approaches in Teacher Education. In J. C. Richards and D. Nunan (Eds.) Second Language Teacher Education. Cambridge: Cambridge University Press.

Rudduck, J. (1991) Innovation and Change. Buckingham: Open University Press.

Schon, D. A. (1983) The Reflective practitioner: How professionals think in action. Aldershot: Ashgate Publishing.

Tripp, D. (1985) 'From autopilot to critical conscious: Problematising successful teaching.' Paper presented at the Sixth Conference on Curriculum and Classroom Practice. Dayton, Ohio.

Wajnryb, R. (1992). Classroom observation tasks. Cambridge: Cambridge University Press.

Wallace, M. J. (1991). Training foreign language teachers. Cambridge: Cambridge University Press.

Williams, M. and R. L. Burden (1997). Psychology for language teachers: A social constructive approach. Cambridge: Cambridge University Press. 